\title{
Qualitative Study of Exclusive Breastfeeding Success among Working Mother
}

\author{
Prameswari, Galuh Nita \\ Department of Nutrition, Faculty \\ of Sports Science \\ Universitas Negeri Semarang \\ (UNNES) \\ Semarang, Indonesia \\ nitagisela@mail.unnes.ac.id
}

\author{
Kurnia, Arif Rahmat \\ Department of Nutrition, Faculty \\ of Sports Science \\ Universitas Negeri Semarang \\ (UNNES) \\ Semarang, Indonesia \\ arifrk@mail.unnes.ac.id
}

\begin{abstract}
Infant Mortality Rate in Indonesia was 32 deaths per 1000 live births, whereas Under-five Mortality Rate reaches 40 deaths from 1000 live births. One of the factors which underlie those numbers was the low rate of exclusive breastfeeding. In Central Java, exclusive breastfeeding was still below target $(80 \%)$, one of the main problem was working mother. This study aims to describe exclusive breastfeeding success in working mothers. This research used qualitative descriptive method by using phenomenology approach which yields descriptive data about the problems. The main subjects were mothers whom succeeded in exclusive breastfeeding (6 months) which data taken using in-depth interview. Respondents were selected using snowball sampling method, then confirmed using source triangulation method. Data analysis was done by transcription, reduction, coding, data presentation, and then drawing conclusion or verification. The results showed that the family and co-workers support also pre-natal preparation were common factors found in working mothers who succeeded in exclusive breastfeeding. The existence of support from the hospital and early breastfeeding initiation was also done by most of them.
\end{abstract}

Keywords- exclusive breastfeeding, working mother, qualitative research

\section{INTRODUCTION}

High infant mortality rates were a huge problem in Indonesia. In 2012, Indonesia Demographic and Health Survey (SDKI) showed the infant mortality rates in Indonesia was 32 per 1000 live births, or only $6 \%$ lower from the 2007 data [1]. Those data showed that Indonesia was struggling to reduce its child mortality rate. It means that Indonesia may not be able to fulfill its 2030 Sustainable Development Goals (SDGs) target to reduce child mortality rate into 12 per 1000 live births (32\% from 2012 data).

One effort to reduce child mortality rate is exclusive breastfeeding. Exclusive breastfeeding was to only feed breast milk to infants for the first 6 months of life. They must not be given any other kind of food and beverage, except for vitamins, minerals, or drugs prescribed by health professionals. There were several benefits related to exclusive breastfeeding such as, reducing infection risk (e.g. diarrhea, urinary tract infection/ UTI), ear infection, and lower respiratory tract infection), and reducing chronic illness risks (e.g. diabetes, sudden infant death syndrome, diabetes, and obesity). Breastmilk contains immunoglobulin which prevent babies from infections. Mother with HIV/ AIDS could prevent its transmission to their babies by exclusive breastfeeding[2]. These findings suggest that giving exclusive breastfeeing had huge benefits to the infants even after they have grown.

Several policies had been made by Indonesian government to support exclusive breastfeeding. Minister of Health already made several policies in this issue, such as: Keputusan Menteri Kesehatan RI No. 450/Menkes/SK/IV/2004, UU No. 36/2009, and PP No. 33/2012, which specify exclusive breastfeeding as baby which exclusively fed breast milk from $0-6$ months and suggested to continue until 2 years with proper complementary feeding [3]. Despite of those rules, the breastfeeding coverage in Indonesia was still lower than target $(<80 \%)$. In central Java, the exclusive breastfeeding coverage also had been stagnant, 53\% (2013), 61\% (2014), 62\% (2015), and 54\% (2016) [1].

Research done on a textile company in Jakarta concluded three factors supporting breastfeeding practice among working mothers, there are knowledge on storing breast milk and breastfeeding practice in workplace, availability of breastfeeding facility, endorsement from health care workers, and support of company supervisor [4]. Exclusive breastfeeding practice among working mothers must be improved using various interventions because of its benefits to the babies, mothers, and companies. A few of the working mothers had done exclusive breastfeeding practice, so it was important for us to do research aiming to describe the story behind success of the working mothers in doing exclusive breastfeeding. There were eleven research question we use to describe this phenomenon.

\section{MATERIALS AND METHODS}

\section{A. Research Focus}

The general objective of this research was to describe the exclusive breastfeeding success on working mothers. The specific objectives of this research were to answers all research questions described on the paragraph above. Focus of this research is to describe all factors related to working mothers' success in practicing exclusive breastfeeding. This research covered several areas, including preparation before birth, on 
maternal leave, right before work, after came back to work, breast milk management, support from families, co-workers, superiors, and health workers, also challenges and solutions on exclusive breastfeeding periods $(0-6$ months old $)$.

\section{B. Research Design}

This study was qualitative descriptive type which produces data to describe problems. Qualitative research could develop concepts that help deeper understanding of social phenomena and behavior in a natural setting. This qualitative research used phenomenology approach, a study that seeks the "essence" or meaning of a phenomenon experienced by the participants [5]. Using phenomenology approach, this study was expected to produce data which describe exclusive breastfeeding success on working mothers which will be presented in the narration.

\section{Source of Information}

This qualitative research was using purposive and snowball sampling method. In purposive sampling researcher choose participants rather than be randomized. Participants chosen according to several criteria which enabled researcher to only select the important ones as key informants. After chosen, they will be asked to suggest other possible participants for this research. This method was known as snowball sampling.

Snowball sampling was chosen because data about working mother which successfully practicing exclusive breastfeeding was limited. This limitation made us combine purposive sampling for choosing key informant, and snowball sampling to cover data saturation. By nature, qualitative study could not determine exact minimum samples. Addition of new participants could be stopped once the data is saturated or repeat itself.

This study got help from Indonesian Breastfeeding Mothers' Association (Asosiasi Ibu Menyusui Indonesial AIMI) to choose key informant. The criteria for key informants are: (1) Working mother who successfully practice exclusive breastfed its baby for 6 months. (2) The child must be born in the last 2 years. (3) Minimum working hours was 5 hours per day. (4) Participant was agreed to be interviewed. (5) Participant is communicative.

\section{Research Instrument and Data Collection Technique}

The data collection technique in this qualitative research was in-depth interview, an interview technique trying to dig deeper into participant's experience. The instrument used in this study was a set of interview guidelines to get information about the experience of working mothers who successfully provide exclusive breastfeeding to their babies, which include: (1) What are things prepared and performed by the working mother during pregnancy, maternity leave, before return to work and after came back to work, for her baby successful exclusive breastfeeding? (2) How was the mechanism of pumping and saving pumped milk during working hour for exclusive breastfeeding success? (3) How was the breastfeeding management for exclusive breastfeeding success? (4) How was the support from family, work environment (superiors or co-workers), and health worker to working mother for exclusive breastfeeding success? (5) What are the challenges faced by working mother during the exclusive breastfeeding period and their solutions for exclusive breastfeeding success?

The materials used to support data collection in addition to interview record book where researchers written the interview process were tablet to record sound and take picture so that all data or information gathered could be recorded properly and completely.

\section{E. Data Validity Check}

In order to avoid or eliminate subjectivity, the data validity was cross checked using triangulation. Triangulation was a method used by researchers to check back the validity of data obtained from the results of in-depth interview with research participants. There are several types of triangulation, and this study was using source triangulation, which means collecting data and checking data validity through different sources of information (participants).

Triangulation of sources or informants were done by doing in-depth interview whose impacting mothers in their successful exclusive breastfeeding, which includes the family (husband or parent or in-laws or other), the work environment (superiors or co-workers), health workers (doctors or midwives). The criteria of informants as cross check or triangulation were, (1) Informant is in the research area. (2) Willing to be interviewed. (3) Easy to communicate with.

\section{F. Data Analysis Technique}

In qualitative data analysis, the presentation was based on data or information from in-depth interviews which collected from many resources, analyzed, then concluded. The researcher sought to highlight important statements from the sample to provide basic understanding of the phenomenon under study. The data analyzed was in accordance with the research problem which will be described in the report as description or narration. Data analysis on this qualitative research using interactive model, which includes the following sequences: (1) Data collection: data were collected from indepth interviews written in field notes and written "as it is" in transcript. (2) Data reduction: data collected in the form of field notes was combined into one transcript form, and then the useless data was discarded; given a coding or category made by researchers which had a particular meaning in accordance with the research questions (as shown in table 1). (3) Data presentation: decrypting data in a narrative. The participants were kept confidential by obscuring any identities. (4) Conclusion/ verification: data were discussed and compared with theories or results from the previous research. Conclusion was taken using induction method, which was drawing conclusion from specific to general things, then reported descriptively. 
TABLE 1 QUALITATIVE DATA REPORT

\begin{tabular}{|c|c|c|}
\hline Ind & & \\
\hline & hh & ah: \\
\hline $\begin{array}{l}\text { Pre } \\
\text { dur } \\
\text { Pre }\end{array}$ & $\begin{array}{l}\text { often read articles about breastfeeding and the kind } \\
\text { food for nursing mothers. I have an elder sister who } \\
\text { rks and give exclusive breastfeeding, and then I ask } \\
\text { advice from her, for the other things, I see from } \\
\text { tagram." (Participant 4) }\end{array}$ & $\begin{array}{l}\text { "Baca-baca artikel tentang menyusui dan makanan untuk } \\
\text { ibu menyusui. Sebelum ada searching-searching ada } \\
\text { kakak aku dia juga ibu bekerja dan ASI Eksklusif terus } \\
\text { minta saran dari dia, lainnya ya lihat-lihat di instagram } \\
\text { gitu." (Participant 4) }\end{array}$ \\
\hline $\begin{array}{l}\text { Preparation } \\
\text { during } \\
\text { Maternity } \\
\text { Leave }\end{array}$ & $\begin{array}{l}\text { ave, I directly breastfeed my baby } \\
\text { ay of delivery, I started to pump } \\
\text { nilk. the pumped milk stock was } \\
\text { go back to work." (Participant } 4 \text { ) }\end{array}$ & $\begin{array}{l}\text { "Pas cuti langsung menyusui dari payudara sama pas } \\
\text { masuk lima hari baru aku mulai pumping buat stok. Pas } \\
\text { aku cuti full, bayi menyusu langsung sama aku, cuma itu } \\
\text { buat jaga-jaga, persiapan ASI buat adek." (Participant 4) }\end{array}$ \\
\hline $\begin{array}{l}\text { Preparation } \\
\text { before the } \\
\text { End of } \\
\text { Maternity } \\
\text { Leave }\end{array}$ & $\begin{array}{l}\text { ly I educated my family about } \\
\text { giving pumped milk to infant and then } \\
\text { e my baby, because when the work } \\
\text { d, for the first time trained, my child } \\
\text { drink milk unless directly through me } \\
\text { I need to teach how (to give pumped } \\
\text { pant 4) }\end{array}$ & $\begin{array}{l}\text { "Ya itu, yang jelas memberikan edukasi ke keluarga, } \\
\text { persiapan memberikan ASI ke adik itu gimana, terus cara } \\
\text { menangani adik gimana, karena kan waktu mau masuk } \\
\text { kerja, saat pertama kali dilatih adik nggak mau minum } \\
\text { susu kecuali langsung lewat aku (payudaraku), jadinya, } \\
\text { perlu ngajarin itunya (memberikan ASI perah.)." } \\
\text { (Participant 4) }\end{array}$ \\
\hline $\begin{array}{ll}\text { vities on } \\
\text { king } \\
\text { s }\end{array}$ & $\begin{array}{l}\text { er } 2 \text { hours working before lunch time and } \\
\text { r lunch time. When I am staying in my } \\
\text { I pump there. But when I have meeting in } \\
\text { s, I will bring my pumping stuff, so } \\
\text { is, I can still pump my breast milk" } \\
\text { 1) }\end{array}$ & $\begin{array}{l}\text { "Saya pumping setelah } 2 \text { jam masuk } \\
\text { siang, lalu saya pompa lagi } 2 \text { jam } \\
\text { Kalau pas saya dikantor ya merahny } \\
\text { ada pertemuan diluar saya membaw } \\
\text { antisipasi. Dimana saja tempatnya } \\
\text { oke saya melakukan pumping." (Part }\end{array}$ \\
\hline $\begin{array}{l}\text { Milk } \\
\text { ing and } \\
\text { anism }\end{array}$ & $\begin{array}{l}\text { "No, sometimes if my breast feels hard, I will } \\
\text { massage first, if not, just straight pumping." } \\
\text { (Participant 4) } \\
\text { "There are two bottles which I put directly to the } \\
\text { breast, after set, I put the timer on the phone and } \\
\text { pressing the pump. Not manual, I use an electric } \\
\text { pumping." (Participant 4) }\end{array}$ & $\begin{array}{l}\text { "Ndak, kadang si terkadang kalau keras banget aku pijet } \\
\text { dulu kalau ndak ya langsung aja si." (Participant 4) } \\
\text { "Ya kan botolnya kan dua langsung aku tempelin aja, } \\
\text { udah nempel baru aku setting timer nya di hape terus } \\
\text { baru aku pencet alat pumpingnya. Nggak manual, } \\
\text { pakainya elektrik." (Participant 4) }\end{array}$ \\
\hline $\mathrm{Pl}$ & then $\mathrm{p}$ & $\begin{array}{l}\text { "Diberikan } 2 \text { jam } \\
\text { sebelum } 2 \text { jam, ASI }(p\end{array}$ \\
\hline & $\begin{array}{l}\text { first son to take } \\
\text { er and in-laws were }\end{array}$ & $\begin{array}{l}\text { "Awalnya tidak me } \\
\text { memberikan informa } \\
\text { anak pertama untuk } \\
\text { mendukung pada akh }\end{array}$ \\
\hline $\begin{array}{l}\text { Wo } \\
\text { Eny }\end{array}$ & $\begin{array}{l}\text { uperior) did } \\
\text { me to bring } \\
\text { t a time." }\end{array}$ & $\begin{array}{l}\text { "Ketika saya } \\
\text { beban kerja y } \\
\text { mengizinkan sa } \\
\text { jika memang dil }\end{array}$ \\
\hline $\begin{array}{l}\text { Roles } \\
\text { Health } \\
\text { Workers }\end{array}$ & $\begin{array}{l}\text { "Got formula milk from doctor, because I ride } \\
\text { different car, at home my child almost drank formula } \\
\text { milk." (Participant 5) } \\
\text { "There was nurse with lactation specialization, nurse } \\
\text { on baby room pumps breast milk manually. And gave } \\
\text { breast milk directly to the baby (Participant 3) }\end{array}$ & $\begin{array}{l}\text { "Dapat susu formula dari dokter, karena saya beda } \\
\text { mobil, hampir waktu di rumah anak saya diberi susu } \\
\text { formula." (Participant 5) } \\
\text { "Ada perawat yang khusus laktasi, perawat di ruang bayi } \\
\text { memompa ASI walaupun manual. Dan memberikan ASI } \\
\text { langsung ke bayi."(Participant } 3 \text { ). }\end{array}$ \\
\hline or EDS & & $\begin{array}{l}\text { a udah tak biarin } \\
\text { itu jadi dikejar aja }\end{array}$ \\
\hline
\end{tabular}




\section{RESULTS AND DISCUSSION}

\section{A. Participant Descriptions}

The participants of this study were working mothers who successfully practiced exclusive breastfeeding. The snowball sampling was stopped when the data was saturated. In this study, the data was saturated on the fifth participants so the triangulation also five peoples ranging from families to coworkers. The youngest participant aged 24 years old and the oldest was 33 years old. All participants had a high degree of formal education (undergraduate degrees and above), most participants had one child; only 1 participant had 2 children. Of the five participants of the study, there was a spontaneous natural birth and the others had a cesarean section. On the day of interviews, the babies age ranging from 7 months old to 13 months old, all of them were girls, with normal baby weight (more than 2,500 grams). All participants work either as lecturers or as employees. The results of in-depth interviews on working mothers describe things related to exclusive breastfeeding success.

\section{B. Preparation during Pregnancy}

At the time of pregnancy, participants prepared themselves by reading most articles from the internet (Instagram), which were about exclusive breastfeeding and correct breastfeeding method, food choices for nursing mothers, and benefits of exclusive breastfeeding. In addition, there was a participant whom participated in seminars on breastfeeding preparation. Other participants got knowledge about exclusive breastfeeding from college. Then, there are also participants who claim to gain knowledge about the exclusive breastfeeding from health workers and from the mother and child health book (KIA Book) she owned since pregnancy. There were also participants whom follow the community of mothers who succeeded in exclusive breastfeeding, especially working mothers, to gain experience; including preparing husbands as "ayah ASI" (to support wives in giving exclusive breastfeeding). One of the participants gained an experience from her elder sister who was a working mother and succeeded to give exclusive breastfeeding.

Mothers should discuss several issues with superiors or coworkers about her decision to breastfeed and work, to make sure whether went home to breastfeed or to breastfeed at work, to confirm time off at working hours were used to breast milking, to ascertain whether in the workplace was a place for breast pumping and pumped milk storage, to find out whether there was a daycare in the workplace or around the work environment and all facilities provided. All participants did preparation started on pregnancy for the success of exclusive breastfeeding.

Some important steps in the success of exclusive breastfeeding for working mothers were also undertaken by research participants, such as to study about breastfeeding and breastfeeding management, to get support from all families, friends and other relatives, to choose a maternity place supporting exclusive breastfeeding, to choose health workers who support exclusive breastfeeding, to look for breastfeeding experts such as Lactation Clinic and Lactation Consultant, to prepare for future difficulties, and to create a positive attitude about pumped milk, breast milk, and breastfeeding.

\section{Preparation during Maternity Leave}

During maternity leave most participants were breastfeeding their baby directly. There was one participant breastfeeding her baby indirectly using pacifier for a month after she gave a birth. This participant said on the very first time of her baby birth, she could not breastfeed directly because of her psychology problems and the tongue-tie of the baby. After those times she could breastfeed her baby directly.

Maternity leave was an important period for the participants to store their pumped milk and keep them frozen. There was a participant whom already starts to pump her breast milk and store it since her fifth day after delivery. Other participants, they started to pump their breast milk on the third month after delivery which means a month before their maternal leave ends so they should go back to work. A participant said that she pumped her milk while her baby was sleeping, therefore she can keep it for their baby and give it on workday. The pumped milk is carefully kept in the freezer or refrigerator and labeled by the date of the pumped milk stored.

All of the participants were happy and grateful that they can breastfeed their baby during maternal leave. The mothers' diet during their maternal leaves should be consisting a lot of water, vegetables, fruits, and various kind of food, without any prohibition or taboo. Before their maternal leave ends, mothers were preparing a nanny or their parents as caretakers for their baby and storing pumped milk. They also gave them knowledge about exclusive breastfeeding and skill about giving pumped milk.

\section{Preparation before The End of Maternity Leave}

Before the end of the leaves, mother could prepare for exclusive breastfeeding success by giving information for parents and caregivers about how to give pumped milk to their baby. Participant also trains the baby to be fed with pumped milk, so that the baby was accustomed with it.

One participant said that the important thing was to prepare pumped milk in the refrigerator. Moreover, the participant also prepared pumping equipment, sterile tools, bottles for milk, and also apron for preparation of breast pumping in the office.

\section{E. Activities on Working Days}

There were few things done by working mothers to successfully exclusive breastfed when they came back to work such as consuming lot of fruits and vegetables, proteins, staple foods, and drink a lot of water.

In the morning before mothers began to work, all of them were breastfeeding their baby. On working hour, there was a participant who chose to pump or breastfeed at home. All participants already had an appropriate management to manage the workload, so it did not cause stress which could affect breast milk production. Another participant had a very good boss, so the participant did not feel overwhelmed on the daily work. Some participants always tried to finish their job exquisitely in the office. 
Relating the sleeping pattern, most participants feel that their rest time was enough 7-8 hours per day. However, there were two participants who feel that their rest time were not enough, because at night they often woke up when the baby awakens. Mothers need to consume highly nutritious foods and drinking enough fluid, to be able to breastfeed the baby in the morning before going to the workplace, and immediately after work, breast pump every 3 hours while working, preparing milk supply in the refrigerator while working, breast milking in a comfortable room while looking at baby photos or viewing baby video recordings, trying to manage the job well so that the mother was not stressed, and had enough rest [6].

\section{F. Breast Milk Pumping and Storing Mechanism}

There was one participant, which was pumping at home because the distance between home and the office was close. She chose to go home for a moment just to pump and then return to the office for work. While the other participants pump in the workplace, with varied mechanisms. Some participants were breast pumping using manual pumping equipment and the others used electric pumps. Equipment brought by mothers from home to the workplace for breast milking were pumps, glass bottles, ice gels, pump chargers, labels, aprons, tissues, and cooler bags.

Breast pumping procedures were performed by participants using some common steps. First was washing their hands until clean. All participants washed their hands before breast pumping; coincidentally the hand washing facility was available at the workplace. There was a participant that said she usually did breast massage before breast pumping and there was another participant who never massage her breast before breast pumping. On the other hand, most participants answered that sometimes they massage their breast before breast pumping. Massage was only done if the breast felt hard or swollen.

Most participants did not use the breast milking courier service to brought breast milk from the office to home. Breast milk brought by mother and stored after returning home. But there was also participant who says that she had used online transport services to deliver her breast milk back home, but that was only occasionally or when needed.

The time required to breast pumping was varied, ranging from 20 minutes to 1 hour. The amounts of breast milk obtained in each breast pumping period at the office were from $45 \mathrm{ml}$ to $300 \mathrm{ml}$.

\section{G. Pumped Milk Management}

When the mother worked in the office, person who gave the pumped milk at home were a nanny or grandmother or the relatives. During mothers working time in the office, babies were given pumped milk for every 2 hours. If the baby was crying or fussy before 2 hours then the pumped milk still be given. So, the breast milk was given to the baby as needed.

All participants did monitoring at the office, by calling or sending a short message via Whats App to the grandmother or caretaker at home. Usually the participant asked if the milk had been given to the baby, and how many bottles of milk given to the baby. Breast milk was given to the baby during mother working time with an average $500 \mathrm{cc}$ per day.

\section{H. Family Supports}

All participants said that their husband, parents, and in-laws are supporting their decision to practice exclusively breastfeeding. A participant said that at first her parents and inlaws were disagreed with her decision, but after explaining to them, they understood and agree to help her success. Another participant said that her mother came to her home to support exclusive breastfeeding. As for husband, all of them are supporting and wish the best for their wives and children.

Family was the closest people which mothers could rely on. Information gave by family had emotions so it will have greater impact to the mother [7]. So, family supports and involvements will be guaranteed a successful exclusive breastfeeding.

\section{Working Environments}

Working environment was important in making sure a successful exclusive breastfeeding. Work environment consists of policies, facilities, superiors, and co-workers which must be supportive. All participants said that their workplace supports breastfeeding although some did not have complete facilities to breast pump.

The supportive environment made the entire working mothers feeling little to no pressure in pumping their breast milk. Both superiors and co-workers were endorsing exclusive breastfeeding practice. Some were even reduced the workload of the mothers, and for other at least they did not harass the breastfeeding mother.

The breastfeeding-friendly environment was integral part of breastfeeding promotion which could increase coverage of exclusive breastfeeding practice [8]. In the US, there were several projects which tried to promote breast-feeding friendly environment such as: breastfeeding-friendly child care centers, breastfeeding-friendly child care award, etc.

Most of the companies are supporting breastfeeding because of new state law in Indonesia. UU no 13/ 2003 explained lactating room must be silent, clean, had enough room (minimal $3 \times 4$ sqm), had good circulation, and had a sink. Equipment needed were manual/ electric breast pump, bottles to store breast milk, refrigerator (ice bag), bottle sterilization tool, and cooler bag [4]. Other than working environment, we found that communities also played role in successful exclusive breastfeeding. Most of the participants were joining AIMI. Two participants did not join AIMI, one had access to its counselor. The participant who did not join community were using internet to search information about exclusive breastfeeding. In AIMI they share and disseminate information about exclusive breastfeeding, and also had discussion group about issues relating to breastfeeding practice. Right information was crucial, so positive surroundings (from families or communities) were important in keeping enthusiasm to breastfed [9]. 


\section{J. Roles of Health Workers}

Health workers were important in making sure the exclusive breastfeeding was done properly. It was known that some health workers promote infants formula to their patients [3]. Their promotion largely succeeds because bearing and birthing child was deeply affect mother. Mothers wanted the best for their infants, so they generally accept suggestions which gave positive impact to their children [5]. One participant had met with health worker (doctor) who did not support exclusive breastfeeding by gave formula milk to the family.

Health workers were impacting exclusive breastfeeding success. Most participants reported that their doctors/ midwifes/ nurses are supporting exclusive breastfeeding. Support from health workers did not stop on the delivery days but continued to the ward care. One participant reported that she had been visited by her doctor for antenatal care evaluation. Those support improved patient understanding about exclusive breast feeding and also boost their confident.

There was no integrated information system about breastfeeding. Integrated system which done by NICU nurses were effective to educate mother about exclusive breastfeeding and debunk any false feeding beliefs [10]. This made breastfeeding information only partially given to the mothers.

\section{K. Challenges and Solutions in Exclusive Breastfeeding Success}

There were several challenges for working mother to breastfed on office hours. The prominent problems were the availability of lactating room and support from co-workers. This problem described by participant 2 .

Other problems were irregular teaching schedule and administrative jobs given to her. She was not only obliged to teach, but also preparing documents for accreditation. This will become problem, because baby usually breastfed when hungry so it will unpredictable.

One of the solutions was by training baby to breastfed regularly or called scheduled breastfeeding method. This method may not be proven in clinical trials yet, but some studies already shown a good trend over baby-led breastfeeding [11]. The problem with scheduled breast pumping was that there are several times it did not went according to work schedule.

\section{CONCLUSION}

The results showed that family and co-workers support were commonly found in successful exclusive breastfeeding. Pre-natal preparation, knowledge about breastfeeding management, and understanding about breast milk pumping also founded in some successful working mothers. The existence of support from the hospital and early breastfeeding initiation also looked importance in some mothers. Only one participant reported the success of exclusive breastfeeding also attributed from the older children support.

\section{ACKNOWLEDGMENT}

The author acknowledges help from Indonesian Breastfeeding Mothers' Association (Asosiasi Ibu Menyusui Indonesial AIMI) which provide platform to help us connect with eligible participants. We declare that there are no conflict of interest regarding to data collection, analysis, and presentation.

\section{REFERENCES}

[1] BKKBN, "Demographic and health survey Indonesia 2012," 2013.

[2] R. L. Shapiro et al., "Infant Morbidity, Mortality, and Breast Milk Immunologic Profiles among Breast- Feeding HIV- Infected and HIV- Uninfected Women in Botswana," J. Infect. Dis., vol. 196, no. 4, pp. 562-569, 2007.

I. U. Tarigan and N. K. Aryastami, "Knowledge, Attitudes, and Behavior of Infant Mothers on Exclusive Breastfeeding," Bul. Penelit. Sist. Kesehat., vol. 15, no. 4, pp. 390-397, 2012.

A. Rizkianti, P. Rachmalina, Novianti, and I. Saptarini, "Analysis of Success Factors of Exclusive Breast-Feeding Practices at Workplace in Textile Industry Workers in Jakarta," Bul. Penelit. Kesehat., vol. 42, no. 4, pp. 237-248, 2014.

[5] M. Watkinson, C. Murray, and J. Simpson, "Maternal experiences of embodied emotional sensations during breast feeding: An Interpretative Phenomenological Analysis," Midwifery, vol. 36, pp. 53-60, 2016.

[6] P. Hoddinott, L. C. A. Craig, J. Britten, and R. M. McInnes, “A serial qualitative interview study of infant feeding experiences: idealism meets realism," BMJ Open, vol. 2, no. 2, p. e000504, Mar. 2012.

[7] N. L. Hawley et al., "Mothers' attitudes and beliefs about infant feeding highlight barriers to exclusive breastfeeding in American Samoa," Women and Birth, vol. 28, no. 3, pp. e80-e86, 2015.

[8] Bureau of Family Health and Nutrition, Guidelines for Breastfeeding Initiation and Support Revised 2008. Massachusetts: Massachusetts Department of Public Health, 2008.

[9] M. Wibowo, "Information Support for Breastfeeding Mothers In Giving Exclusive Breast Milk In Gondokusuman Sub-District of Yogyakarta City," J. Kesehat. Masy., vol. 11, no. 2, p. 241, Feb. 2016.

[10] R. Cricco-Lizza, "Infant Feeding Beliefs and Day-to-Day Feeding Practices of NICU Nurses," J. Pediatr. Nurs., vol. 31, no. 2, pp. e91-e98, 2016.

[11] A. Fallon, D. Van der Putten, C. Dring, E. H. Moylett, G. Fealy, and D. Devane, "Baby-led compared with scheduled (or mixed) breastfeeding for successful breastfeeding," Cochrane database Syst. Rev., vol. 7, no. 9, 2014. 